\title{
Kajian Efektivitas Insektisida Berbahan Bunga Krisan (Chrysanthemum cinerariaefolium) dan Jeruk Nipis (Citrus aurantifolia) terhadap Mortalitas Nyamuk
}

\author{
Beatrix Clarissa $^{1}$, Rina Priastini Susilowati², Liauw Djai Yen ${ }^{3}$, Budiman Hartono ${ }^{2}$
}

\author{
${ }^{1}$ Fakultas Kedokteran dan Ilmu Kesehatan, Universitas Kristen Krida Wacana, Jakarta, Indonesia \\ ${ }^{2}$ Departemen Biologi, Fakultas Kedokteran dan Ilmu Kesehatan, Universitas Kristen Krida Wacana, \\ Jakarta, Indonesia \\ ${ }^{3}$ Departemen Forensik Bioetik Mediokolegal, Fakultas Kedokteran dan Ilmu Kesehatan, Universitas \\ Kristen Krida Wacana, Jakarta, Indonesia \\ Alamat Korespondensi: beatrix.2017fk192@ civitas.ukrida.ac.id
}

\begin{abstract}
Abstrak
Nyamuk merupakan salah satu vektor penyakit bagi manusia. Habitat tempat tinggal nyamuk erat hubungannya dengan lingkungan tempat tinggal manusia sehingga penularan sangat rawan terjadi. Upaya yang dilakukan untuk mengurangi insidensi tersebut salah satunya yaitu dengan penggunaan insektisida sintesis maupun bioinsektisida. Bioinsektisida memiliki keunggulan lebih aman terhadap manusia, hewan, serta ramah lingkungan. Tinjauan pustaka ini bertujuan untuk mengkaji efektivitas insektisida berbahan bunga krisan dan jeruk nipis terhadap mortalitas nyamuk. Penelusuran kepustakaan dilakukan menggunakan Google Scholar, Emerald, PubMed dan Proquest dengan kata kunci Chrysanthemum AND LC $_{50}$ AND mosquito dan Citrus aurantifolia $A N D \mathrm{LC}_{50}$ AND mosquito. Dua puluh tiga makalah dipilih untuk penulisan tinjauan pustaka ini. Keefektivan Chrysanthemum sp. dan Citrus aurantifolia sebagai insektisida dapat dilihat dari nilai $\mathrm{LC}_{50}$ yang didapatkan. Nilai $\mathrm{LC}_{50}$ ekstrak tanaman bunga krisan berkisar antara 0,02\% - 1,50\% dan ekstrak jeruk nipis berkisar 0,108\% - 40,087\%. Chrysanthemum sp. dan Citrus aurantifolia merupakan tanaman yang dapat digunakan sebagai bahan pembuatan insektisida.
\end{abstract}

Kata Kunci : insektisida, jeruk, krisan, nyamuk

\section{Study on the Effectiveness of Insecticides Made of Chrysanthemum (Chrysanthemum cinerariaefolium) and Lime (Citrus aurantifolia) against Mosquitoes Mortality: A Review}

\begin{abstract}
Mosquitoes are vectors of human diseases. The habitat where mosquitoes live is closely related to the environment where humans live so that transmission is very prone to occur. One of the efforts to reduce the incidence is the use of synthetic insecticides and bioinsecticides. Bioinsecticides have the advantages of being safer for humans, animals, and being environmentally friendly. This literature review was conducted with the aim of investigating the effectiveness of insecticides made of chrysanthemum and lime flowers on mosquito mortality. Literature searches are carried out using Google Scholar, Emerald, PubMed and Proquest with the keywords Chrysanthemum AND LC $C_{50}$ AND mosquito and Citrus aurantifolia AND LC $C_{50} A N D$ mosquito. Twenty-three papers were selected for the literature review. The effectiveness of Chrysanthemum sp. and Citrus aurantifolia as an insecticide can be seen from the $L C_{50}$ values obtained. The $L C_{50}$ values of chrysanthemum plant extract ranged from $0.02 \%-1.50 \%$ and lime extract ranged from $0.108 \%-40.087 \%$. Chrysanthemum sp. and Citrus aurantifolia can be used as ingredients for making insecticides.
\end{abstract}

Keywords : insecticide, orange, chrysanthemum, mosquito

How to Cite :

Clarissa B, Susilowati RP, Yen LD, Hartono B. Kajian Efektivitas Insektisida Berbahan Bunga Krisan (Chrysanthemum cinerariaefolium) dan Jeruk Nipis (Citrus aurantifolia) terhadap Mortalitas Nyamuk. J Kdokt Meditek. 2021;27(2): 157-163. Available from:

http://ejournal.ukrida.ac.id/ojs/index.php/Meditek/article/view/2022 DOI: https://doi.org/10.36452/ikdoktmeditek.v27i2.2022 


\section{Pendahuluan}

Nyamuk merupakan salah satu vektor penyakit bagi manusia. Berbagai spesies nyamuk seperti Aedes aegypti, Aedes albopictus, Anopheles sp., dan Culex sp., dapat membawa berbagai jenis penyakit seperti Demam Berdarah Dengue (DBD), chikungunya, malaria, filariasis, dan sebagainya. ${ }^{1}$ Indonesia merupakan negara yang sering menghadapi kasus penyakit yang disebabkan vektor nyamuk. World Health Organization (WHO) mencatat negara Indonesia sebagai negara dengan kasus DBD tertinggi di Asia Tenggara terhitung sejak tahun 1968 hingga tahun 2009. ${ }^{2}$ Habitat tempat tinggal nyamuk ini erat hubungannya dengan lingkungan tempat tinggal manusia sehingga penularan sangat rawan terjadi. ${ }^{3,4}$

Berbagai upaya telah dilakukan oleh pemerintah dan masyarakat untuk pengendalian nyamuk seperti melakukan 3M yaitu menguras tempat penampungan air, mengubur barang bekas, dan menutup tempat penampungan air. Namun cara ini kurang efektif sehingga upaya lain harus dilakukan untuk mengurangi insidensi penyakit, salah satunya yaitu dengan penggunaan bioinsektisida nyamuk. Sediaan insektisida nyamuk yang dijual di pasaran kebanyakan menggunakan campuran bahan kimia diethylmetatoluamide (DEET) dan permethrin yang dapat menyebabkan pencemaran lingkungan, peninggalan residu, dan menyebabkan resistensi. ${ }^{5-}$

${ }^{7}$ Pada dosis tinggi residu yang tertinggal dapat terserap oleh kulit dan menyebabkan kejang otot, sedangkan pada kulit sensitif dapat menyebabkan iritasi. $^{6,7}$ Untuk mengurangi hal tersebut dilakukanlah penggunaan bioinsektisida atau insektisida yang berasal dari tumbuh tumbuhan.

Insektisida adalah suatu zat kimia, jasad renik, virus, atau bahan lainnya yang digunakan untuk memberantas serangga yang dapat mebahayakan kesehatan atau menganggu manusia. ${ }^{8}$ Insektisida yang terbuat dari tumbuhan atau disebut juga insektisida botani, dianggap lebih aman dan ramah lingkungan. Insektisida ini memiliki jangka waktu residu lebih pendek dan efek samping yang lebih kecil dibandingkan dengan insektisida yang berbagan sintesis.
Tanaman krisan dan jeruk nipis mengandung fitokimia yang memiliki aktifitas insektisida. Tanaman krisan memiliki kandungan piretroid yang berfungsi merusak sistem saraf nyamuk. ${ }^{1}$ Begitu juga dengan kulit buah, daun, dan bulir buah tanaman jeruk nipis. Bagian tanaman buah ini memiliki kandungan bahan aktif. Beberapa senyawa bioaktif yang diduga terkandung diantaranya yaitu limonen, geraniol, flavonoid, tanin, saponin, dan triterpenoid yang bersifat racun kontak dan racun pernafasan pada nyamuk. ${ }^{6}$ Namun salah satu kekurangan dari insektisida berbahan tanaman krisan yaitu insektisida cepat menguap. Karena kedua ekstrak memiliki jenis kandungan insektisida yang berbeda, maka campuran kedua ekstrak tersebut diharapkan dapat memiliki daya bunuh nyamuk yang lebih baik (sinergis).

Pengujian efektivitas suatu ekstrak tanaman sebagai bioinsektisida dapat dilakukan dengan menguji dan menghitung Lethal Concentration 50 $\left(\mathrm{LC}_{50}\right) \cdot{ }^{10} \mathrm{LC}_{50}$ adalah nilai konsentrasi yang dapat membunuh 50\% dari total subjek yang diuji. ${ }^{2,6}$

Tujuan penulisan literature review ini adalah untuk mengkaji efektivitas insektisida berbahan bunga krisan dan jeruk nipis terhadap mortalitas nyamuk dengan melihat nilai $\mathrm{LC}_{50}$.

\section{Metodologi}

Kajian kepustakaan dilakukan dengan pendekatan deskriptif, berdasarkan pustaka dari artikel atau jurnal penelitian yang relevan dengan tema penelitian. Penelusuran kepustakaan dilakukan dengan Google Scholar, Emerald, PubMed dan Proquest. Kata kunci yang digunakan dalam pencarian yaitu Chrysanthemum $A N D \mathrm{LC}_{50}$ AND mosquito dan Citrus aurantifolia AND $\mathrm{LC}_{50}$ AND mosquito. Kriteria inklusi penelitian yaitu jurnal penelitian atau text book yang membahas tentang Chrysanthemum dan Citrus aurantifolia sebagai insektisida nyamuk, dipublikasikan pada tahun 2011-2020, berbahasa Indonesia atau Inggris, dan memiliki tema yang sesuai. Kriteria eksklusi penelitian yaitu jurnal yang tidak dapat ditampilkan full text, tujuan jurnal tidak relevan, metode penelitian pada jurnal tidka dijelaskan dengan baik, dan subjek yang digunakan bukan nyamuk. 


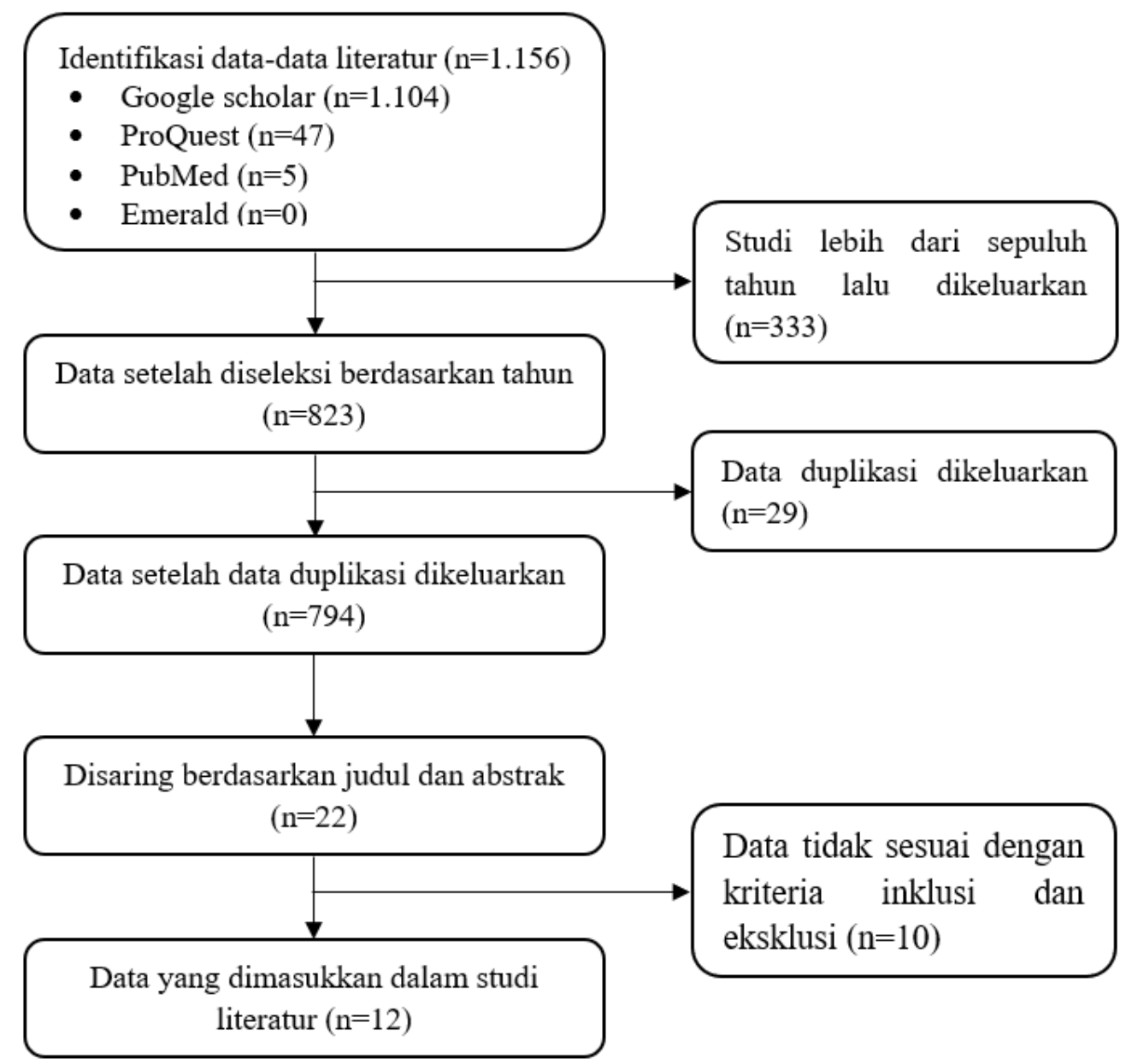

Gambar 1. Seleksi Studi dan Penilaian Kualitas

Hasil

Tabel 1. Tanaman yang Memiliki Daya Insektisida terhadap Ae. aegypti

\begin{tabular}{|c|c|c|c|c|}
\hline $\begin{array}{c}\text { Spesies } \\
\text { Tanaman }\end{array}$ & $\begin{array}{c}\text { Bagian } \\
\text { Tanaman }\end{array}$ & Metode Penelitian & LC50 & Pustaka \\
\hline $\begin{array}{l}\text { Chrysanthemum } \\
\text { cinerariaefolium }\end{array}$ & Bunga & $\begin{array}{l}\text { Uji eksperimental } \\
\text { dengan memberikan } \\
\text { paparan uap larutan } \\
\text { ekstrak ke nyamuk } A e . \\
\text { aegypti dewasa. }\end{array}$ & $\begin{array}{l}\text { Nilai } \mathrm{LC}_{50} \text { yang didapat } \\
\text { yaitu } 0,49 \% \text { dalam waktu } \\
24 \text { jam. Pada kelompok } \\
\text { kontrol tidak terdapat } \\
\text { kematian pada nyamuk. }\end{array}$ & (9) \\
\hline $\begin{array}{l}\text { Chrysanthemum } \\
\text { morifolium }\end{array}$ & Bunga & $\begin{array}{l}\text { Uji eksperimental } \\
\text { dengan merendam telur } \\
\text { Ae. aegypti. }\end{array}$ & $\begin{array}{l}\mathrm{LC}_{50} \text { yang didapat yaitu } \\
0,268 \% \text {. Pada kelompok } \\
\text { kontrol semua telur } \\
\text { menetas. }\end{array}$ & (10) \\
\hline $\begin{array}{l}\text { Chrysanthemum } \\
\text { indicum }\end{array}$ & Daun & $\begin{array}{l}\text { Uji eksperimental } \\
\text { dengan merendam } \\
\text { larva Anopheles sp. }\end{array}$ & $\begin{array}{l}\text { Nilai } \mathrm{LC}_{50} \text { pada ekstrak } \\
\text { methanol } C \text {. indicum } \\
\text { terhadap larva Anopheles } \\
\text { sp. didapatkan pada } \\
\text { konsentrasi } 0,02 \% \text {. Pada } \\
\text { kelompok kontrol tidak } \\
\text { terdapat mortalitas larva. }\end{array}$ & (11) \\
\hline
\end{tabular}




\begin{tabular}{|c|c|c|c|}
\hline $\begin{array}{l}\text { Chrysanthemum } \\
\text { indicum }\end{array}$ & Daun & $\begin{array}{l}\text { Uji eksperimental } \\
\text { dengan merendam } \\
\text { larva An. subpictus } \\
\text { dan } C u . \\
\text { Tritaeniorhynchus. }\end{array}$ & $\begin{array}{l}\mathrm{LC}_{50} \text { pada } A n . \text { subpictus } \\
\text { didapatkan } 39,98 \mathrm{mg} / \mathrm{L} \\
(0,0399 \%) . \\
\mathrm{LC}_{50} \text { pada } C u . \\
\text { tritaeniorhynchus } \\
\text { didapatkan } 42,29 \mathrm{mg} / \mathrm{L} \\
(0,0422 \%) .\end{array}$ \\
\hline $\begin{array}{l}\text { Chrysanthemum } \\
\text { morifolium }\end{array}$ & Daun & $\begin{array}{l}\text { Uji eksperimental } \\
\text { dengan merendam } \\
\text { larva Ae. albopictus. }\end{array}$ & $\begin{array}{l}\text { Nilai } \mathrm{LC}_{50} \text { yang } \\
\text { didapatkan yaitu } 1,50 \% \\
\text { dalam waktu } 24 \text { jam. }\end{array}$ \\
\hline $\begin{array}{l}\text { Citrus } \\
\text { aurantifolia }\end{array}$ & Kulit buah & $\begin{array}{l}\text { Uji eksperimental } \\
\text { dengan memberikan } \\
\text { paparan ekstrak } \\
\text { terhadap nyamuk } \\
\text { dewasa Ae. aegypti. }\end{array}$ & $\begin{array}{l}\text { Nilai } \mathrm{LC}_{50} \text { ekstrak kulit } \\
\text { buah Citrus aurantifolia } \\
\text { yaitu } 40,087 \% \text {. Pada } \\
\text { kontrol negatif tidak } \\
\text { ditemukan adanya } \\
\text { nyamuk yang mati. }\end{array}$ \\
\hline $\begin{array}{l}\text { Citrus } \\
\text { aurantifolia }\end{array}$ & Daun & $\begin{array}{l}\text { Uji eksperimental } \\
\text { dengan larva } A e . \\
\text { aegypti. }\end{array}$ & $\begin{array}{l}\text { Ekstrak metanol daun } \\
\text { Citrus aurantifolia } \\
\text { menyebabkan } \\
\text { mortalitas larva } \\
\text { nyamuk Ae. aegypti } \\
\text { dengan LC } \text { L }_{50} \text { adalah } \\
2.197 \text { ppm }(0,2197 \%) \text {. } \\
\text { Pada kelompok kontrol } \\
\text { negatif tidak ditemukan } \\
\text { kematian larva. }\end{array}$ \\
\hline $\begin{array}{l}\text { Citrus } \\
\text { aurantifolia }\end{array}$ & Daun & $\begin{array}{l}\text { Uji eksperimental } \\
\text { dengan larva } A e . \\
\text { aegypti. }\end{array}$ & $\begin{array}{l}\text { Nilai } \mathrm{LC}_{50} \text { yang } \\
\text { didapatkan adalah } \\
0,108 \% \text {. Pada kontrol } \\
\text { negatif tidak ditemukan } \\
\text { kematian larva. Aktivitas } \\
\text { larvasida } \\
\text { ekstrak metanol daun } \\
\text { jeruk } \\
\text { nipis terhadap larva Ae. } \\
\text { aegypti } \\
\text { lebih rendah } \\
\text { dibandingkan Temephos } \\
(\mathrm{K}+) .\end{array}$ \\
\hline $\begin{array}{l}\text { Citrus } \\
\text { aurantifolia }\end{array}$ & Bulir Buah & $\begin{array}{l}\text { Uji eksperimental } \\
\text { dengan larva } A e . \\
\text { albopictus. }\end{array}$ & $\begin{array}{l}\text { Nilai } \mathrm{LC}_{50} \text { yang } \\
\text { didapatkan dari ekstrak } \\
\text { ethanol } 60 \% \text { bulir buah } \\
\text { C. aurantifolia yaitu } 2,95 \\
\mathrm{mg} / \mathrm{mL}(2,95 \%) \text {. Abate } \\
(\mathrm{K}+) \text { dapat menyebabkan } \\
100 \% \text { kematian pada } \\
\text { konsentrasi } 0,5 \% \text {. }\end{array}$ \\
\hline $\begin{array}{l}\text { Citrus } \\
\text { aurantifolia }\end{array}$ & Daun & $\begin{array}{l}\text { Uji eksperimental } \\
\text { dengan larva } A e . \\
\text { aegypti. }\end{array}$ & $\begin{array}{l}\text { Nilai } \mathrm{LC}_{50} \text { yang } \\
\text { didapatkan yaitu } \\
23,499 \% \text {. }\end{array}$ \\
\hline
\end{tabular}




\begin{tabular}{|c|c|c|c|}
\hline $\begin{array}{l}\text { Citrus } \\
\text { aurantifolia }\end{array}$ & Daun & $\begin{array}{l}\text { Uji Eksperimental } \\
\text { dengan rancangan } \\
\text { secara acak dengan tes } \\
\text { dan kelompok kontrol. }\end{array}$ & $\begin{array}{l}\text { Nilai } \mathrm{LC}_{50} \text { ekstrak daun } \\
\text { jeruk nipis (Citrus } \\
\text { aurantifolia) berada pada } \\
\text { konsentrasi } 1,271 \mathrm{gr} / \mathrm{liter} \\
(1,271 \%) \text {. }\end{array}$ \\
\hline $\begin{array}{l}\text { Citrus } \\
\text { aurantifolia }\end{array}$ & Kulit buah & $\begin{array}{l}\text { Uji Eksperimental } \\
\text { dengan merendam } \\
\text { larva pada larutan } \\
\text { ekstrak. }\end{array}$ & $\begin{array}{l}\text { Nilai } \mathrm{LC}_{50} \text { ekstrak kulit } \\
\text { Citrus aurantifolia yang } \\
\text { didapatkan yaitu 3,419\%. } \\
\text { Pada kelompok kontrol } \\
\text { negatif tidak ditemukan } \\
\text { adanya kematian larva. }\end{array}$ \\
\hline
\end{tabular}

\section{Pembahasan}

\section{Efektivitas Ekstrak Chrysanthemum sp. Sebagai Bioinsektisida}

Dari hasil penelusuran jurnal penelitian, didapatkan nilai $\mathrm{LC}_{50}$ ekstrak tanaman bunga krisan berkisar antara 0,02\% - 1,50\%. Beberapa spesies tanaman bunga krisan yang dapat terbukti dapat menyebabkan kematian pada nyamuk yaitu: Chrysanthemum cinerariaefolium, Chrysanthemum morifolium, dan Chrysanthemum indicum.

Tanaman Chrysanthemum dianggap menjadi salah satu genus tanaman penghasil insektisida. Senyawa yang aktif sebagai insektisida pada tanaman ini adalah piretrin. Senyawa piretrin merupakan campuran dari 6 komponen yaitu, Piretrin I dan II, Sinerin I dan II, serta Jasmolin I dan II. ${ }^{11}$ Piretrin memiliki korelasi negatif terhadap suhu, yang berarti daya racun piretrin pada suhu rendah akan meningkat. ${ }^{11}$

Piretrin memiliki kemampuan kerja yang cepat. Cara kerja piretrin yaitu dengan meracuni sistem saraf pada serangga. Senyawa ini menyebabkan kelumpuhan dan pada akhirnya mematikan serangga. Meski begitu piretrin aman untuk penggunaan pada manusia dan hewan peliharaan, mudah terurai sehingga tidak meninggalkan residu racun pada lingkungan maupun makanan. ${ }^{11}$

\section{Efektivitas Ekstrak Citrus aurantifolia Sebagai Bioinsektisida}

Berdasarkan hasil penelusuran jurnal penelitian, nilai $\mathrm{LC}_{50}$ dari ekstrak daun Citrus aurantifolia yaitu berkisar $0,108 \%-23,499 \%$, nilai $\mathrm{LC}_{50}$ dari ekstrak kulit buahnya yaitu $3,415 \%$ dan $40,087 \%$, sedangkan $\mathrm{LC}_{50}$ dari bulir buahnya yaitu $2,95 \%$.
Bagian tanaman Citrus aurantifolia yang terbukti dapat dimanfaatkan sebagai bahan pembuatan insektisida yaitu kulit, daun, dan bulir buahnya. Kulit buah Citrus aurantifolia mengandung limonen, sitronelal, geraniol, $\beta$ kariofilen dan $\alpha$-terpineol, linalol, neril asetat, dan trans- $\beta$-osimen. ${ }^{19}$ Bagian daunnya mengandung flavonoid, saponin, tanin, dan triterpenoid. ${ }^{23}$ Sedangkan pada bulir buahnya mengandung kadar senyawa limonen yang tinggi dan terpenoid. ${ }^{16}$

Kerja limonen yaitu dengan mengambat pergantian kulit pada larva. ${ }^{15}$ Limonen dapat masuk ke bagian pencernaan nyamuk. Insektisida akan diserap oleh dinding pencernaan kemudian beredar dalam tubuh nyamuk. ${ }^{15}$ Pada akhirnya nyamuk akan mengalami gangguan aktivitas dan mati. ${ }^{15}$ Geraniol merupakan senyawa fenol yang dapat menimbulkan bau aroma khas yang mengakibatkan nyamuk gagal mengenali makanannya dan pergi. ${ }^{6}$ Flavonoid adalah senyawa golongan fenol yang menyebabkan penggumpalan protein. Denaturasi protein akan menyebabkan permeabilitas dinding sel dalam saluran pencernaan menurun. Hal ini akan mengakibatkan gangguan transport nutrisi yang akhirnya mengakibatkan kematian larva. Tanin merupakan golongan fenolik yang menghambat protein yang diperlukan larva untuk pertumbuhan. Saponin memiliki kemampuan merusak membran sehingga pada larva senyawa ini menyebabkan korosi dinding traktus digestivus larva. Selain itu saponin juga merusak lapisan lipoid pada epikutikula sehingga menyebabkan mudahnya masuk zat toksik ke dalam tubuh larva. Triterpenoid mengakibatkan terhambatnya pergantian kulit pada larva, selain itu triterpenoid yang masuk kedalam pencernaan larva akan mengakibatkan kurangnya energi untuk aktivitas. Hal ini menyebabkan larva kejang dan mati. 


\section{Perbandingan Efektivitas Chrysanthemum sp. dan Citrus aurantifolia Sebagai Bionsektisida}

Semakin rendah nilai $\mathrm{LC}_{50}$ maka semakin tinggi nilai toksisitas insektisida tersebut. ${ }^{24}$ Kisaran nilai $\mathrm{LC}_{50}$ dari Chrysanthemum sp. adalah 0,02\% $1,50 \%$, sedangkan Citrus aurantifolia adalah 0,108\% - 40,087\%. Dari hasil tersebut didapatkan bahwa Chrysanthemum sp. memiliki toksisitas yang lebih tinggi dibandingkan dengan Citrus aurantifolia. Variasi nilai $\mathrm{LC}_{50}$ dari kedua tanaman tersebut diduga karena perbedaan kualitas tanaman, cara pembuatan ekstrak, atau pelarut yang digunakan untuk melarutkan ekstrak dan sebagainya.

\section{Simpulan}

Berdasarkan pencarian literatur dapat disimpulkan bahwa Chrysanthemum cinerariaefolium dan Citrus aurantifolia dapat digunakan sebagai bahan kimia aktif penyusun insektisida. Keefektifannya sebagai insektisida dapat dilihat dari nilai $\mathrm{LC}_{50}$ pada nyamuk.

\section{Daftar Pustaka}

1. Dinata A. Bersahabat dengan nyamuk: jurus jitu atasi penyakit bersumber nyamuk. Ed. Revisi. Pangandaran: Penerbit Arda Publishing; 2018. 18-40 p.

2. Astriani Y, Widawati M. Potensi tanaman di indonesia sebagai larvasida alami untuk Aedes aegypti. Spirakel. 2017;8(2):37-46.

3. Rahayu DF, Ustiawan A. Identifikasi Aedes aegypti dan Aedes albopictus. Balaba. 2013;9(1):7-10.

4. Pusarawati S, Ideam B, Kusmartisnawati, Tantular IS, Basuki S. Atlas parasitologi kedokteran. Santoso SHB, Dachlan YP, Yotopranoto S, editors. Jakarta: Penerbit Buku Kedokteran EGC; 2018. 118-120 p.

5. Isnaningsih DMS. Pengaruh ekstrak bunga krisan (Chrysanthemum cinerariaefolium) terhadap fekunditas dan fertilitas Aedes aegypti. J Higeia J Public Heal Res Dev. 2018;2(1):1-10.

6. Saleh M, Susilawaty A, Syarfaini S, Musdalifah M. Uji efektivitas ekstrak kulit buah jeruk nipis (Citrus aurantifolia) sebagai insektisida hayati terhadap nyamuk Aedes aegypti. Hig $\mathbf{J}$ Kesehat Lingkung. 2017;3(1):30-6.
7. Aini R, Widiastuti R, Afra N, Politeknik N, Setya B, Yogyakarta I. Uji efektifitas formula spray dari minyak atsiri herba kemangi (Ocimum sanctum L) sebagai repellent nyamuk Aedes aegypti. J Ilm Manuntung. 2016;2(2):189-97.

8. Gunawan J, Makimian R, Dewi R. Uji efektivitas ekstrak minyak atsiri bunga krisan aster putih (Chrysanthemum cinerariaefolium) sebagai bioinsektisida terhadap nyamuk Aedes aegypti. Damianus J Med. 2020; 1-8.

9. Mayangsari I, Umiana S T, Sidharti L, Kurniawan B. The effects of krisan flower (Chrysanthemum morifolium) extract as ovicide of Aedes aegypti's egg. J Major. 2015;4(5):29-34.

10. Mukadam M. Larvicidal activity of some medicinal plant extracts against Anopheles. Int J Trend Res Dev. 2016;4(1):22-4.

11. Kamaraj C, Bagavan A, Elango G, Abduz Zahir A, Rajakumar G, Marimuthu S, et al. Larvicidal activity of medicinal plant extracts against Anopheles subpictus and Culex tritaeniorhynchus. Indian J Med Res. 2011; 134(1):101-6.

12. Zamin Khan G, Khan A, Khan I. Exploiting the larvicidal properties of Parthenium hysterophorus $\mathrm{L}$ for control of dengue vector, Aedes albopictus. Pak J Weed Sci Res. 2014;20(4):431-8.

13. Adrianto $\mathrm{H}$, Hamidah. Evaluasi toksisitas ekstrak metanol daun jeruk nipis (Citrus aurantifolia) terhadap kematian larva nyamuk Aedes aegypti. Aspirator. 10(1):57-63.

14. Musiam S, Armianti M, Putra AMP. Uji biolarvasida ekstrak metanol daun jeruk nipis (Citrus aurantifolia) terhadap larva nyamuk Aedes aegypti. J Ilm Ibnu Sina. 2018;3(1):5563.

15. Nishan M, Subramanian $P$, Saahatish R. Toxicity of Citrus aurantifolia and Citrus hystrix against Aedes albopictus larvae. Int $\mathbf{J}$ Biosci. 2017;10(06):48-54.

16. Monica R, Khomsatun. Efektivitas perasan daun jeruk nipis (Citrus aurantifolia) terhadap kematian larva Aedes aegypti instar III di laboratorium Loka Litbang p2b2 Ciamis Jawa Barat. Keslingmas. 2018;37(2):101-239.

17. Saputra EJ, Pakkan R. Efektivitas ekstrak daun jeruk nipis (Citrus aurantifolia) dan batang serai wangi (Cymbopogon nardus L) terhadap kematian jentik Aedes aegypti di Kelurahan Lapulu Kecamatan Abeli. Miracle J Public Heal. 2018;1(2):1-8. 
18. Ekawati ER. Pemanfaatan kulit buah jeruk nipis (Citrus aurantifolia) sebagai larvasida Aedes aegypti instar III. Biota. 2017;3(1):1.

19. Hendri J, Kusnandar AJ, Astuti EP. Identifikasi jenis bahan aktif dan penggunaan insektisida antinyamuk serta kerentanan vektor DBD terhadap organofosfat pada tiga kota endemis dbd di provinsi Banten. Aspirator - $\mathbf{J}$ Vector-borne Dis Stud. 2016;8(2):77-86.

20. Boesri HB, Heriyanto B, Susanti L, Handayani SW. Uji repelen (daya tolak) beberapa ekstrak tumbuhan terhadap gigitan nyamuk Aedes aegypti vektor demam berdarah dengue. Vektora J Vektor dan Reserv Penyakit. 2015;7(2):79-85.

21. Kardinan A, Wikardi E, Dhalimi A, Juhono J, Iskandar M. Kajian aplikasi insektisida nabati piretrum (Chrysanthemum cineariaefolium) pada pertanaman kubis petani. Bul Penelit Tanam Rempah dan Obat. 2019;10(1):14-24.

22. Wibaldus, Jayuska A, Ardiningsih P. Biokativitas minyak atsiri kulit buah jeruk nipis (Citrus aurantifolia) terhadap rayap tanah (Coptotermes sp.). J Kim Khatulistiwa. 2016;5(1):44-51.

23. Margareta RP, Agastia CW. Aktivitas antibakteri ekstrak perasan daun mengkudu (Moringa citrifolia L.) terhadap Escherichia coli secara in vitro. J Ris Kefarmasian Indones. 2020;2(1).

24. Dheasabel G, Azinar M. Kemampuan ekstrak buah pare terhadap kematian nyamuk Aedes aegypti. Higeia J Public Heal Res Dev. 2018;2(2):331-41. 